\title{
EMPLOYEE VOICE, HUMAN RESOURCE PRACTICES, AND QUIT RATES: EVIDENCE FROM THE TELECOMMUNICATIONS INDUSTRY
}

\author{
ROSEMARY BATT, ALEXANDER J.S. COLVIN, and JEFFREY KEEFE*
}

\begin{abstract}
The authors draw on strategic human resource and industrial relations theories to identify the sets of employee voice mechanisms and human resource practices that are likely to predict firm-level quit rates, then empirically evaluate the predictive power of these variables using data from a 1998 establishmentlevel survey in the telecommunications industry. With respect to alternative voice mechanisms, they find that union representation predicts lower quit rates, even after they control for compensation and a wide range of other human resource practices that may be affected by collective bargaining. Also predicting lower quit rates is employee participation in offline problem-solving groups and in self-directed teams. No apparent association is found between quit rates and the availability of nonunion dispute resolution procedures. Regarding human resource practices, higher relative wages and internal promotion policies predict lower quit rates, and contingent staffing, electronic monitoring, and variable pay predict higher rates.
\end{abstract}

$\mathbf{H}$ igh quit rates are a significant cost to organizations, both because they raise labor costs (Oi 1962) and because they lower organizational performance (for example, Norsworthy and Zabala 1986). Research in industrial relations has shown that unionized establishments have signifi-

*Rosemary Batt is Associate Professor of Human Resource Studies, Industrial and Labor Relations School, Cornell University; Alexander J.S. Colvin is Assistant Professor of Labor Studies and Industrial Relations, Pennsylvania State University; and Jeffrey Keefe is Associate Professor, School of Management and Labor Relations, Rutgers University. This research is based on a multi-year study of the telecommunications services industry conducted in collaboration with Harry Katz and generously funded by the Alfred P. Sloan Foundation. The authors thank Harry Katz for comments on prior versions of the draft and Danielle van Jaarsveld for her careful research assistance. cantly lower quit rates than nonunion establishments because they provide a voice mechanism through which employees can negotiate higher relative compensation and redress problems as an alternative to exit (Freeman and Medoff 1984). More recent research on "high commitment" or "high performance" work systems has shown that coherent sets of human resource practices lead to lower quit rates (for example, Arthur 1994) and better organizational performance (for example, Ichniowski et al. 1996), and that high quit rates undermine perfor-

A data appendix with additional results, and copies of the computer programs used to generate the results presented in the paper, are available from the first author at the New York State School of Industrial and Labor Relations, 387B Ives Hall, Cornell University, Ithaca, NY 14853. 
mance (Alexander, Bloom, and Nuchols 1994; Huselid 1995). High performance practices include those that invest in the skills of the work force and provide the opportunity and incentives for employees to use those skills effectively (for example, Appelbaum et al. 2000).

Over the past decade or so, however, firms have adopted a wide range of nonunion voice mechanisms and cost-cutting human resource practices that have not been considered in the industrial relations or high performance literature. Alternative voice mechanisms include different types of nonunion dispute resolution procedures as well as team-based work organization. Cost-cutting human resource (HR) practices include downsizing and contingent staffing and pay, which are likely to decrease employee commitment to the firm.

In this study, we examine a comprehensive set of voice and human resource practices that are likely to influence employee quit rates. We consider quit rates at the establishment level rather than at the individual level of analysis so that we can identify the specific management practices that influence quit rates-a subject of particular interest in periods of tight labor markets. In contrast to the high performance literature, which generally examines clusters of HR practices taken together, we examine individual practices in order to disaggregate the unique and potentially contradictory relationships between specific management practices and quit rates. We consider these issues among a relatively under-studied group of workers: moderately and highly skilled service, sales, and technical employees. To do so, we examine a unique 1998 data set on a nationally representative sample of union and nonunion establishments in the telecommunications industry.

\section{Voice Mechanisms as Deterrents to Turnover}

The exit-voice framework (Hirschman 1970) identifies a range of circumstances in which markets may fail to provide organizations with effective feedback and in which customer or employee voice might lead to improved organizational performance. Voice, as defined by Hirschman, is any attempt to change rather than escape from an unsatisfactory situation. In the employment context, voice involves the expression of dissatisfaction by employees; exit occurs when employees quit. The design of work and human resource practices is likely to influence the balance between employee voice and exit. The exit-voice framework provides a model of the political economy of organizations, where exit belongs to the realm of economics and voice to the realm of politics.

In recent years, employers have adopted alternative forms of voice, both as part of high performance work systems and as substitutes for unions. Employers have viewed team-based work systems as providing opportunities for collective voice or direct participation in shop-floor decisions, and nonunion dispute resolution procedures as providing opportunities for individual voice to redress employee grievances. In the following sections, we consider the theoretical importance of these alternative mechanisms as predictors of quit rates.

\section{Unions as Collective Voice}

In the most important application of the exit-voice model to employment, Freeman and Medoff (1984) provided evidence linking union voice to higher productivity and lower quit rates. Unions reduce the probability that workers will quit their jobs for two fundamental reasons. First, unions provide a voice mechanism through which workers gain higher compensation than they could earn in a similar nonunion job. Second, unions provide workers with a voice in determining an array of other rules and conditions of work, including policies that reduce pay inequality, grievance and arbitration procedures for appealing managerial decisions, "just cause" for discipline and discharge, and seniority clauses desired by workers.

Empirical research supports the view that union mechanisms affecting both wages and voice lead to lower quit rates in union 
establishments. Freeman (1980a), for example, found that union establishments had lower quit rates even when his analysis controlled for wage rates. Other researchers have replicated this finding in the United States (for example, see Cotton and Tuttle 1986; Wilson and Peel 1991) as well as in other countries (Miller and Mulvey 1991; Lincoln and Kalleberg 1996).

Recent research, however, has challenged this general view. In a study of truckers in the 1990s, for example, Delery et al. (2000) found that the statistically significant relationship between quit rates and unionization disappeared when wages and benefits were taken into account. They concluded that the union effect operated entirely through compensation. They suggested that union decline may be affecting unions' ability to influence employee voice and quit behavior, but they admitted that their findings are industry-specific and could be accounted for by the independent nature of truck drivers' jobs and their greater attachment to their occupation than to their employers. Thus, Delery et al. (2000) reopen the union voice debate by questioning whether unions in the 1990s were strong or effective enough as voice mechanisms to influence employee quit behavior.

Another stream of recent research has found that at the individual level, employee use of voice mechanisms is positively, not negatively, correlated with employee intent to quit and subsequent turnover (Lewin and Boroff 1996; Boroff and Lewin 1997; Lewin and Peterson 1999). This latter body of research suggests a distinction not recognized in much of the standard exit-voice theory: whereas quit rates may be lower in enterprises where stronger voice mechanisms are available, among enterprises that have similar voice mechanisms available to employees, greater usage of these voice mechanisms may be associated with higher quit rates.

\section{Teams as Collective Voice}

In the high performance literature, teambased work systems generally are viewed as improving performance by providing work- ers (those closest to the point of production) with the opportunity to collaborate in solving problems and improving the production process. Much less attention has been paid to teams as voice mechanisms that allow dissatisfied workers to voice their concerns, and thereby reduce the likelihood that they will quit. Those studies that have found an inverse relationship between high performance practices and quit rates have included team participation only as part of a cluster of practices (for example, Arthur 1994; Huselid 1995). Other studies that have examined individual HR practices and quit rates have found mixed results. For example, Delery et al. (2000) found no relationship between employee participation and quit rates in the trucking industry (see also Shaw et al. 1998).

A large body of research in organizational behavior, however, has found that employees with "enhanced or enriched jobs" (for example, those with greater autonomy, variety, or ability to complete a whole task) have higher job satisfaction and lower turnover (Hackman and Oldham 1980; McEvoy and Cascio 1985; Cotton and Tuttle 1986; Hom and Griffeth 1995). The question, therefore, is whether the opportunity for voice provided by different types of team formations is sufficient to reduce the propensity to quit. If teams are merely supervised groups with little discretion to affect conditions at work, then their influence on quits will be minimal.

In general, researchers have distinguished between two types of team participation: consultative and substantive (Levine and Tyson 1990). Consultative forms include participation in problem-solving groups that meet periodically and allow employees to voice their opinions to management. Substantive forms include the organization of work into self-managed or semi-autonomous teams that have considerable responsibility for making day-to-day decisions without consulting management.

Empirical research in the teams or group effectiveness literature provides mixed results on whether these different forms of team voice lower turnover. Consultative forms have a significant but modest posi- 
tive relationship to employee behavior and performance (Cotton 1993; Cohen and Bailey 1997). Substantive participation in self-managed teams has a significant, and appreciably greater, positive relationship to a range of employee behaviors and performance, but specific studies of turnover have yielded mixed results. For example, Cordery et al. (1991) found that autonomous teams have higher turnover rates than non-autonomous teams. Weisman et al. (1993) found that nurses in self-managed teams worked longer hours (increasing turnover), but had higher pay (decreasing turnover). Other studies have found that alternative forms of voice can reduce employee turnover (Bemmels 1997). For example, Spencer (1986) found a negative relationship between turnover rates and number of voice mechanisms (such as grievance procedures, survey feedback, and suggestion systems). In sum, theory suggests that team participation programs may provide employees with enough voice to reduce turnover, but the research record is mixed.

\section{Nonunion Dispute \\ Resolution Procedures: Employee Voice or Voice Suppression?}

Employers also have designed a variety of dispute resolution procedures in nonunion settings, including procedures for management review of grievances, peer review, and nonunion arbitration, that may provide an individualized form of voice in the workplace and thereby reduce quit rates. There is no empirical research on the relative effectiveness of these alternative procedures for reducing quit rates, but studies of variation in union grievance procedures have found that procedures providing relatively stronger protections for workers are associated with lower quit rates. Rees (1991), for example, examined collectively bargained grievance procedures and found that relatively stronger procedures more effectively reduced quit rates than did weaker procedures. In Delery et al.'s trucking study (2000), formal grievance procedures were negatively related to quit rates, but the relationship became statistically insignificant in regression equations that controlled for unionization. Their measure of grievance procedures, however, did not distinguish between weaker and stronger forms of procedures. We seek to understand which types of nonunion dispute procedures provide workers with enough voice to reduce quit rates.

Many nonunion dispute resolution procedures provide a formal structure through which employees can appeal disputes with supervisors to higher levels of management. These may range from simple procedures in which an individual manager reviews written complaints to more elaborate procedures involving hearings of complaints before appeal boards composed of seniorlevel managers. Under these types of nonunion procedures, managers hold decisionmaking authority (Ewing 1989; Feuille and Delaney 1992). Under peer review procedures, by contrast, employee complaints are evaluated by a panel composed predominantly of the complainant's peers. Presumably, employees are more willing to trust the effectiveness of a procedure in which their fellow employees decide grievances (Ewing 1989; Colvin 1999). However, as employees of the company, peer review panelists are not comparable to third party neutrals used in arbitration or mediation procedures. Also, peer review decisions lack the legal enforceability of union grievance-arbitration procedures, and thus depend on the good faith of management.

Nonunion arbitration emerged during the 1990 s as the most prominent and rapidly expanding variety of nonunion dispute resolution procedure using non-managerial decision-makers. An important danger posed by these individual employee arbitration agreements is their potential to suppress employee voice. In Gilmer $v$. Interstate/Johnson Lane, 500 U.S. 20 (1991), the Supreme Court deferred to employer-sponsored arbitration procedures to resolve disputes over statutory rights. Individual employee arbitration contracts often are compulsory because employees must agree to arbitration as a condition of employment at the time of hire or, in some instances, as a 
condition of continuing employment or future promotions or benefits (Stone 1996, 1999). They require that an employee submit any alleged violation of state or federal law to a company-designed arbitration procedure. By agreeing to arbitration, the employee forgoes any opportunity to pursue his or her claim in court. Both the design of nonunion arbitration procedures and the decisions of arbitrators are heavily insulated from judicial review (Stone 1996, 1999). Whether this innovation enhances or suppresses employee voice is at the center of a major controversy. Some observers suggest that compulsory arbitration creates opportunities for due process in nonunion workplaces (Zack 1999), while others suggest it represents a significant curtailment of employee rights (Stone 1996, 1999). Current research suggests that the more effective employees perceive the grievance procedure to be, the more likely they will exercise the voice option rather than quit (Boroff and Lewin 1997). If employees perceive nonunion arbitration to be directed primarily at limiting their statutory employment rights, they may be less likely to use these procedures as mechanisms for voice and more likely to quit.

Predictions about the relationship between dispute resolution procedure usage rates and employee quit rates are uncertain. Higher usage rates may indicate that employees view nonunion procedures as effective voice mechanisms. If so, then we would expect higher usage rates to be associated with lower quit rates. However, extensive research on unionized workplaces indicates that higher grievance rates are associated with higher levels of workplace conflict and reduced organizational performance (Katz, Kochan, and Gobeille 1983; Katz, Kochan, and Weber 1985; Norsworthy and Zabala 1986; Ichniowski 1986; CutcherGershenfeld 1991). These higher levels of workplace conflict associated with higher grievance rates also may raise quit rates. A positive relationship between grievance rates and quit rates is also suggested by research indicating that individuals who file grievances are more likely to quit than are other employees (Lewin 1987; Lewin
1990; Lewin and Peterson 1999). These individual-level studies have focused primarily on variation in usage of voice mechanisms, rather than on variation in the presence of voice mechanisms. This is in part because previous research has concentrated on unionized workplaces, which have less variation in grievance procedures than nonunion workplaces do, and hence has not examined the effect of simultaneous variation in both the type of procedure and the usage or dispute rate (Lewin 1999). The greater variation in the incidence and structure of dispute resolution procedures in the nonunion sector (Feuille and Delaney 1992; Colvin 1999) permits examination of the question of how variation both in the type of dispute resolution procedure and in dispute rates affects aggregate quit rates. Our prediction is that greater availability of dispute resolution procedures to employees should be associated with lower quit rates, but that, holding the availability of procedures constant, higher grievance rates should be associated with higher quit rates.

\section{Human Resource Practices and Quit Rates}

Historically, the design of internal labor markets encouraged long-term employment, fostered by a set of interrelated human resource policies designed to reduce quit rates (Doeringer and Piore 1971; Schacht 1985; Jacoby 1985). Internal ladders provided a series of promotional steps that continually expanded the employees' firm-specific skill sets and rewarded them with higher pay at each step. In exchange, employers gained a loyal and stable work force with high levels of firm-specific skills, amortizing the quasi-fixed cost of employment over many years of employee tenure. The high performance literature draws heavily on internal labor market theory (emphasizing investment in skills and training and long-term employment relations); but it also includes newer practices such as teams and performance-based pay (for example, Osterman 1994b).

Empirical research does show that commitment-enhancing internal labor market 
practices reduce quit rates. Firm-specific training (Miller and Mulvey 1991) and higher pay (Leonard 1987; Powell, Montgomery, and Cosgrove 1994; Shaw et al. 1998; Delery et al. 2000) are associated with lower quit rates. Cappelli and Chauvin (1991) found that wage premiums or high unemployment in the outside market resulted in greater reliance on grievance procedures-presumably because the exit alternative was more costly. Meta-analyses of research in organizational behavior also find support for internal labor market theory (for example, Cotton and Tuttle 1986; Hom and Griffeth 1995:40), with lower turnover among employees who are satisfied with promotion opportunities, perceive their employment to be secure, or have higher relative pay or pay satisfaction. Finally, studies of high performance systems have shown that turnover is lower in workplaces that adopt a cluster of high commitment practices (Arthur 1994; Huselid 1995).

Over the last decade or so, however, firms have been dismantling internal labor markets (for example, Cappelli 1999; Osterman 1999) in an attempt to enhance labor flexibility or their ability to quickly adjust labor costs to variation in product market conditions. The use of cost-cutting HR practices (including downsizing, subcontracting and outsourcing, contingent and part-time staffing, and contingent pay) has introduced labor market competition inside organizations. The result is that workplaces often have a mix of HR practices that provide contradictory incentives to workers-commitment-enhancing investments in training on the one hand, but greater reliance on contingent staffing and pay, on the other. This use of contradictory HR practices is at odds with the concept of coherence or "bundles" of consistent practices found in the high performance literature (MacDuffie 1995), and suggests that HR practices must be examined individually rather than as clusters or bundles.

Some research is emerging that shows the effects of cost-cutting HR practices on the behavior of "core" employees-those who are regular employees and critical to the business enterprise. Firms that downsize, for example, often do so again (for example, Wyatt 1993), and thereby send a signal to their core employees that future employment is insecure. In response, the more qualified or skilled employees who have alternative employment opportunities are likely to quit. Use of contingent and part-time employees may be used to buffer core employees from job displacement; but recent studies show that firms often use contingent staffing as a cost-cutting strategy (Houseman 2001). In these cases, firms send a signal to core employees that their jobs are insecure because future cost-cutting may lead to converting more core jobs to contingent positions. Again, the more qualified or skilled employees are likely to leave. In the 1990 s, firms often downsized and withdrew employment security commitments while simultaneously using more contingent staffing.

The availability of temporary workers as substitutes for core employees also puts downward pressure on the wages of incumbent employees. Katz and Krueger (1999), for example, in an analysis controlling for unemployment, found that states with a greater share of temporary help employment experienced lower wage growth. They argued that the growth of the temporary help industry and other contingent arrangements facilitated wage restraint by increasing the ability of firms to locate substitute workers. Similarly, establishments that use relatively large numbers of temporary workers as substitutes for core employees, thereby putting pressure on the core employees to accept wage restraint, may find that the wages of core employees fall behind those of competing employers in the external labor market. Thus, by using contingent labor contracts to hold down labor costs, employers unintentionally may be facilitating the exit of their core employees.

In conjunction with downsizing and contingent staffing, some employers have sought to reduce labor costs by standardizing and simplifying job tasks. This re-engineering of tasks reduces training costs and permits electronic monitoring that saves 
on supervision and surfaces performance problems using objective measures. In the context of the telecommunications industry in this study, advanced information systems have provided employers with a major tool for labor cost reduction through task standardization and continuous electronic monitoring. Prior research has demonstrated that such standardization and simplification of jobs and electronic monitoring is associated with higher turnover (Wilson and Peel 1991; Carayon 1993; Shaw et al. 1998).

The greater use of contingent pay may accelerate quit rates because performancebased pay plans increase the variability of workers' pay, and thus their financial uncertainty. Performance-based pay links workers' pay more closely to variability in market conditions, over which workers have little control. Given the relatively risk-averse preferences reflected in the pay plans bargained by unions representing workers (Freeman 1980b and 1982), it is unlikely that variable pay plans have been introduced at workers' request. Most workers rely financially on their paycheck alone, and lack other sources of income or a diversified portfolio to hedge risk. Moreover, most variable pay plans are not accompanied by a compensating wage increase for the greater risk borne by workers.

\section{Expected Findings}

In summary, in this paper we present a model of the predictors of quit rates that includes alternative voice mechanisms and alternative human resource practices (see Figure 1). We hypothesize that union presence will have a negative relationship with quit rates, over and above the effects of the union wage and other voice and human resource practices. We hypothesize that the team-based voice mechanisms will be modestly negatively related to quit rates. The prediction for nonunion dispute resolution procedures is uncertain, as they may be designed to encourage or to suppress employee voice. More effective procedures (for example, peer review panels) should be able to reduce quit rates. Holding the procedure constant, high grievance activity rates should be positively associated with quit rates because they signal higher levels of conflict and greater numbers of problems faced by employees in the workplace.

Finally, quit rates should be lower in workplaces that increase the cost of exit through commitment-enhancing human resource practices such as investment in training, internal mobility opportunities, and high relative pay. Quit rates should be higher, by contrast, in workplaces that have implemented cost-cutting human resource practices-including downsizing, the use of contingent staffing, job standardization and electronic monitoring, and variable pay-each of which signals a lack of employer commitment to employee welfare or long-term employment relations. We expect these relationships to hold after we control for market, organizational, and demographic characteristics, which we discuss in the methods section below.

\section{Methods}

\section{Sample}

The sample is a stratified random sample drawn from the Dun and Bradstreet listing of establishments. Establishments were stratified by size (10-99 employees, 100plus employees), by SIC code (4812, cellular; 4813, wireline; 4841, cable), and by state location. Sixty percent of the sample is in the wireline segment, $15 \%$ in cable television, $14.6 \%$ in cellular, and $6.9 \%$ in Internet services. All establishments with more than 100 employees were sampled so that the survey would cover a large percentage of the industry's work force. Sampling of the remaining smaller establishments was done so that the total sample reflects the relative proportion of establishments in each industry segment of the Dun and Bradstreet listing. Because Internet service providers (ISPs) are new and not systematically captured by SIC code, additional ISPs were identified through the Directory of National Dial-up Providers and Area Codes of Operation.

In the fall 1998, a university-based survey 
team administered an initial telephone survey covering questions related to basic industry characteristics, management strategies, and work and human resource practices. The general manager at each establishment was the respondent. The telephone interview averaged 52 minutes, and yielded a $54 \%$ response rate with 636 usable surveys. Respondents were asked if they were willing to take part in an additional survey on dispute resolution procedures. This yielded a sample of 302 respondents, divided about equally between the two core sides of the business: network operations and service and sales.

\section{Measures and Means}

We used several techniques to reduce measurement problems found in workplace studies. Because human resource practices vary by organizational unit and occupational subgroup (for example, Osterman 1987; Jackson et al. 1989), survey questions asked managers about their "core" nonmanagement group of workers: either net- work technicians or service and sales workers. This strategy follows that of Osterman (1994a), among others. To reduce problems impairing validity, we used only general managers as respondents, as some research shows that general managers are less optimistic than HR managers in their assessments of HR practices (Gerhart 1999). Moreover, general managers oversaw worksites that were relatively small, with an average of 117 core employees per site in the database.

Another way to improve validity and reliability is to base survey questions on field research and to frame questions in language that is context-specific. We conducted field research in numerous network operations and service and sales centers in a range of markets (local, long distance, cellular, cable) and customer segments (residential, small business, middle market). Our survey questions were based on questions from our field interviews that managers were readily able to answer without consulting other documentation. In site visits, we checked these general manag- 
ers' responses against those of subject matter experts in the same organization. Also, we checked the reliability of survey responses against outside data, including the Dun and Bradstreet listing, union contracts in specific companies, and the Current Population Survey (CPS).

The primary dependent variable in this study is the current annual quit rate, based on the question, "As a percentage, what is your annual voluntary quit rate among [network technicians or customer service and sales employees] (excluding discharges, retirements, transfers, and promotions)?" This definition differs from definitions used in most prior studies, which have collapsed voluntary and involuntary turnover (for example, Bennett et al. 1993; Alexander et al. 1994; Arthur 1994; Huselid 1995). It follows the measure of quit rates used by Wilson and Peel (1991), Powell et al. (1994), and Shaw et al. (1998), the last of whom showed that the determinants of discharges and quits are distinct. The independent and control variables fall into four categories: employee voice mechanisms; costcutting human resource practices; commitment-enhancing HR practices; and controls for organizational and work force characteristics.

\footnotetext{
${ }^{1}$ First, we compared our survey items to data contained in the Dun and Bradstreet listing. There were three variables (date establishment founded, primary market, and size) common to both data sets, and the means for each variable in the two data sets were not statistically significantly different. Second, we examined union contracts and found that the wage rates and job titles reported by managers at specific Bell companies were comparable to those in the corresponding union contracts. Third, we compared our survey data to data in the Current Population Survey for the telecommunications industry (CPS 1998). For example, for customer service and sales workers, the most comparable group in the CPS is clerical and sales workers. The 1998 median annual pay in the CPS is $\$ 31,200$ for union clerical and sales workers and $\$ 26,000$ for nonunion workers, compared to $\$ 33,000$ for union workers and $\$ 28,000$ in our sample. The 1998 CPS unionization rate is $32 \%$, while that of our sample is $38 \%$. Given the fact that we oversampled large establishments that tend to pay higher wages and to be more heavily unionized, these comparisons are reasonably consistent.
}

Table 1 reports the means, standard deviations, number of observations, and ranges for all variables used in the study. The average annual quit rate in this sample is $11 \%$. For collective voice, union presence is captured by a dummy variable (where 1 = union, 0 = no union) because the core work force is defined narrowly enough to fall completely within one bargaining unit. Twenty-four percent of the establishments are union-represented. For team participation, we measured consultative participation (whether the establishment makes use of off-line problem-solving groups) as the percentage of employees in the establishment participating in problem-solving teams. We measured substantive participation (whether the establishment makes use of self-directed teams) as the proportion of the establishment's employees organized in self-directed teams. In the average establishment in this survey, $46 \%$ of employees were in problem-solving groups and $19 \%$ were in self-directed work teams.

Dispute resolution procedures covering nonunion core work forces are captured by three dummy variables representing, respectively, any type of formal nonunion grievance procedure, nonunion arbitration, and peer review panels. Usage of these procedures is measured by a single variable consisting of the annual number of grievances or complaints per employee brought under the applicable union or nonunion procedure. The average annual number of disputes was six per 100 employees. Due to the length of the survey and its cost, only a random subsample of 302 of the respondents answered the more detailed set of questions about their dispute resolution procedures.

To capture cost-cutting human resource practices, we included five items: downsizing, electronic monitoring, parttime workers, temporary employees, and variable pay. Downsizing is measured by taking the number of core employees displaced in the past five years as a percentage of the current core work force. Market deregulation, technology advances, and mergers have led to ongoing downsizing 
Table 1. Telecommunications Survey Data: Means, Observations, Standard Deviations, and Ranges.

\begin{tabular}{|c|c|c|c|c|c|}
\hline Variable Name & Obs. & Mean & Std. Dev. & Min. & $\operatorname{Max}$. \\
\hline Annual Quit Rate $\%^{a}$ & 598 & 0.108 & 0.164 & 0 & 1 \\
\hline \multicolumn{6}{|l|}{ Employee Voice } \\
\hline Union \% & 635 & 0.241 & 0.428 & 0 & 1 \\
\hline \multicolumn{6}{|l|}{ Teams: } \\
\hline Problem-Solving Groups \% & 632 & 0.462 & 0.385 & 0 & 1 \\
\hline Self-Directed Teams $\%$ & 632 & 0.193 & 0.341 & 0 & 1 \\
\hline \multicolumn{6}{|l|}{ Dispute Resolution Procedures: } \\
\hline Any Nonunion Procedure $\%$ & 300 & 0.357 & 0.480 & 0 & 1 \\
\hline Nonunion Arbitration \% & 291 & 0.162 & 0.369 & 0 & 1 \\
\hline Peer Review \% & 294 & 0.160 & 0.367 & 0 & 1 \\
\hline Dispute Rate per Employee & 285 & 0.061 & 0.184 & 0 & 2 \\
\hline \multicolumn{6}{|l|}{ Cost-Cutting HR Practices } \\
\hline Downsizing Rate in Last Five Years \% & 633 & 0.092 & 0.011 & 0 & 0.261 \\
\hline Part-Time Workers \% & 630 & 0.053 & 0.135 & 0 & 1 \\
\hline Temporary Workers \% & 611 & 0.041 & 0.137 & 0 & 1 \\
\hline Electronic Monitoring \% & 622 & 0.326 & 0.405 & 0 & 1 \\
\hline Variable Pay \% & 616 & 0.158 & 0.530 & 0 & 1 \\
\hline \multicolumn{6}{|l|}{ Commitment-Enhancing HR Practices } \\
\hline Mobility $\%$ & 611 & 0.438 & 0.367 & 0 & 1 \\
\hline Training (Days per Year) & 636 & 2.025 & 1.652 & 0 & 10 \\
\hline Ratio: Pay to Local Cost of Living & 568 & 0.732 & 0.356 & 0.233 & 3.355 \\
\hline \multicolumn{6}{|l|}{ Control Variables } \\
\hline Female $\%$ & 625 & 0.401 & 0.360 & 0 & 1 \\
\hline Ln of Establishment Employment $\mathrm{t}^{\mathrm{b}}$ & 634 & 4.124 & 1.600 & 0 & 10.959 \\
\hline Branch \% & 636 & 0.794 & 0.405 & 0 & 1 \\
\hline Former Bell Company \% & 636 & 0.264 & 0.441 & 0 & 1 \\
\hline Human Resource Department \% & 633 & 0.428 & 0.495 & 0 & 1 \\
\hline College Graduates \% & 622 & 0.220 & 0.415 & 0 & 1 \\
\hline Field Technicians \% & 636 & 0.275 & 0.447 & 0 & 1 \\
\hline Office Technicians \% & 636 & 0.168 & 0.374 & 0 & 1 \\
\hline Service and Sales Workers \% & 636 & 0.557 & 0.497 & 0 & 1 \\
\hline
\end{tabular}

${ }^{\mathrm{a}}$ All variables listed as $\%$ are scaled from 0 to 1 for consistency. The mean for these variables should be multiplied by 100 to get the actual percentage.

${ }^{b}$ Establishment employment is defined as number of full-time, permanent employees; minimum log of employment 0 because some establishments have only one full-time employee.

and restructuring in this industry. Electronic monitoring is the percentage of a typical employee's daily work time that is electronically monitored; on average, this value is $33 \%$. Contingent staffing includes the percentage of the work force that is temporary (on average, $4 \%$ ) and part-time (on average, 5\%), as opposed to permanent and full-time. Variable pay is the percentage of pay of the typical core employee that is variable-on average, $16 \%$.
For commitment-enhancing HR practices, we measured three dimensions: training, internal mobility opportunities, and pay. Training is the number of weeks of training received by the typical core employee, which is two weeks on average in this sample. Our measure of internal mobility opportunities is the percentage of core employees who were promoted from within the company or transferred from other departments or business units within 
the company; the average is $44 \%$. We include lateral as well as vertical opportunities because lateral opportunities often are valued by employees-for example, for moving to preferred jobs at the same pay, for gaining broader experience for subsequent promotions, or for more convenient work locations closer to home. Pay is the ratio of median pay to the local cost of living. Median pay (the pay received by the typical core worker) was provided by survey respondents. We divided this pay level by the local cost of living, drawn from the Economic Research Institute's (ERI's) Geographic Reference Report, which provides cost of living data for 3,568 North American cities using the "Urban Family of Four" model of analysis. The average ratio of worker pay to local cost of living ( $\$ 35,040$ / $\$ 48,000)$ is 0.73 .

Four variables control for variation in organizational characteristics: size (the natural $\log$ of the total number of employees-4.12, on average, across these establishments); branch location (whether the establishment is part of a larger organization-79\%); Bell company (whether the establishment is owned by a former Bell company-26\%); and presence of an HR department at the establishment $(43 \%)$. Prior research has shown that these organizational characteristics are associated with long-term employment contracts (Rebitzer 1986; Osterman 1994a; Jacoby 1985).

We also controlled for human capital characteristics that are known to influence employees' labor market power and external opportunities. Researchers, for example, have found statistically significant differences in employment tenure by gender, although not when other factors such as occupation or family status are taken into consideration (Osterman 1987; Hom and Griffeth 1995). We measure female composition as the percentage of the core work force that is female, which is $40 \%$ on average. Education also has been found to be associated with higher turnover (Hom and Griffeth 1995:38). In this study, we included a dummy variable for college (where 1 = college degree) because the major educational dividing line is whether employees have a college degree. Twentytwo percent of respondents reported that the typical core employee has a college degree. Occupations are captured by a series of three dummy variables: whether the employee is a service and sales representative (the omitted category), an office technician $(17 \%)$, or a field technician $(28 \%)$.

\section{Results}

In this section, we first report the results of our analysis of voice mechanisms and human resource practices using the full data set (Tables 2 and 3 ). Then, because the alternative dispute resolution variables rely on a subset of the data, we report those results separately (Table 4 ).

Table 2 reports the correlation matrix. The union and team voice variables are significantly correlated with lower quit rates, but the nonunion procedures and dispute rates are not. Each of the cost-cutting human resource practices, except electronic monitoring, is associated with higher quit rates. Internal labor market practices that are associated with lower quit rates at statistically significant levels are internal mobility opportunities and high relative pay; training is not correlated with quits. Some control variables have a statistically significant positive association with higher quit rates, including the percentage of the work force that is female, having a human resource department on site, and the percentage of the work force with college degrees. Other controls, including the percentage of the work force that is field technicians and whether the establishment is part of a former Bell company, are correlated with lower quit rates.

Table 3 presents the results from Tobit analyses in which the dependent variable is regressed on four sets of independent variables: employee (union and team) voice, cost-cutting human resource practices, commitment-enhancing HR practices, and the full model, each with the appropriate controls. We used a Tobit procedure because the dependent variable Quit Rate is trun- 
Table 2. Telecommunications Survey Data: Correlations.

\begin{tabular}{|c|c|c|c|c|c|c|c|c|}
\hline & 1 & 2 & 3 & 4 & 5 & 6 & 7 & 8 \\
\hline 1 Quit Rate & 1.000 & & & & & & & \\
\hline 2 Union & $-0.244 * * *$ & 1.000 & & & & & & \\
\hline 3 Problem-Solving Groups $\%$ & $-0.105^{* *}$ & $-0.253 * * *$ & 1.000 & & & & & \\
\hline 4 Self-Directed Teams $\%$ & $-0.104 * *$ & $-0.089 *$ & $0.261 * * *$ & 1.000 & & & & \\
\hline 5 Downsizing in Last 5 Yrs. & $0.202 * * *$ & -0.038 & 0.046 & -0.029 & 1.000 & & & \\
\hline 6 Part-Time Workers \% & $0.266 * * *$ & $-0.150 * * *$ & -0.026 & 0.009 & 0.101 & 1.000 & & \\
\hline 7 Electronic Monitoring \% & 0.060 & $0.164 * * *$ & -0.002 & 0.026 & -0.037 & $0.122 * * *$ & 1.000 & \\
\hline 8 Variable Pay $\%$ & $0.131 * * *$ & $-0.251 * * *$ & $0.166 * * *$ & 0.062 & 0.015 & 0.039 & $-0.137 * * *$ & 1.000 \\
\hline 9 Temporary Workers $\%$ & $0.171 * * *$ & -0.035 & -0.017 & 0.036 & -0.013 & 0.057 & -0.046 & -0.050 \\
\hline 10 Mobility $\%$ & $-0.169 * * *$ & $0.124 * * *$ & -0.012 & $0.096 * *$ & 0.048 & $-0.101 * *$ & -0.053 & $-0.083^{*}$ \\
\hline 11 Training & -0.039 & -0.010 & $0.116^{*}$ & $0.081 * *$ & -0.045 & $-0.078^{*}$ & 0.035 & $0.110^{* * *}$ \\
\hline 12 Pay to Cost of Living & $-0.140 * * *$ & 0.035 & $0.072 *$ & $0.106 * *$ & -0.069 & $-0.244 * * *$ & $-0.264 * * *$ & $0.268 * * *$ \\
\hline 13 Any Nonunion Procedure & 0.076 & $-0.480 * * *$ & 0.051 & 0.026 & -0.021 & 0.011 & -0.053 & 0.001 \\
\hline 14 Nonunion Arbitration & -0.018 & $-0.289 * * *$ & $0.175 * * *$ & $0.145 * *$ & -0.050 & -0.045 & -0.066 & 0.076 \\
\hline 15 Peer Review & -0.033 & $-0.285 * * *$ & 0.089 & $0.196 * * *$ & 0.044 & 0.030 & 0.003 & 0.101 \\
\hline 16 Dispute Rate per Employee & 0.032 & $0.212 * * *$ & -0.012 & -0.066 & 0.004 & -0.080 & 0.039 & -0.106 \\
\hline 17 Female $\%$ & $0.160 * * *$ & $-0.091 * *$ & $0.084 * *$ & $-0.101 * *$ & $0.076 *$ & $0.204 * * *$ & $0.179 * * *$ & $0.103^{*}$ \\
\hline 18 Ln Estab. Employment & 0.003 & $0.353 * * *$ & $-0.205 * * *$ & $-0.140 * * *$ & $-0.078 *$ & $-0.081 * *$ & $0.238 * * *$ & $-0.147 * * *$ \\
\hline 19 Branch & -0.007 & $0.242 * * *$ & $-0.196 * * *$ & $-0.090 * *$ & $-0.081 * *$ & $-0.116^{* * *}$ & $0.130 * * *$ & -0.006 \\
\hline 20 Former Bell Company & $-0.086^{* *}$ & $0.567 * * *$ & $-0.175^{* * *}$ & -0.069 & 0.051 & $-0.088 * *$ & $0.109 * * *$ & $-0.099 *$ \\
\hline 21 HR Dept. on Premise & $0.109 * * *$ & $0.115^{* * *}$ & $-0.069 *$ & -0.046 & -0.048 & 0.023 & $0.248^{* * *} *$ & -0.056 \\
\hline 22 College Graduate & $0.084 * *$ & $-0.270 * * *$ & $0.159 * * *$ & $0.102 * *$ & -0.028 & $-0.121 * * *$ & $-0.204 * * *$ & $0.371 * * *$ \\
\hline 23 Field Technicians & $-0.216^{* * *}$ & $0.295 * * *$ & $-0.187 * * *$ & -0.013 & -0.028 & $-0.197 * * *$ & -0.046 & $-0.231 * * *$ \\
\hline \multirow[t]{2}{*}{24 Office Technicians } & -0.054 & -0.035 & 0.041 & $0.114 * * *$ & -0.022 & $-0.073^{*}$ & -0.077 & $-0.122 * * *$ \\
\hline & 9 & 10 & 11 & 12 & 13 & 14 & 15 & 16 \\
\hline 9 Temporary Workers $\%$ & 1.000 & & & & & & & \\
\hline 10 Mobility $\%$ & $-0.088^{*}$ & 1.000 & & & & & & \\
\hline 11 Training & -0.019 & 0.008 & 1.000 & & & & & \\
\hline 12 Pay to Cost of Living & -0.047 & 0.068 & 0.064 & 1.000 & & & & \\
\hline 13 Any Nonunion Procedure & 0.000 & 0.018 & 0.001 & -0.022 & 1.000 & & & \\
\hline 14 Nonunion Arbitration & -0.053 & 0.073 & $0.171 * * *$ & 0.028 & $0.269 * * *$ & 1.000 & & \\
\hline 15 Peer Review & -0.094 & 0.050 & $0.128 *$ & 0.021 & $0.419 * * *$ & $0.361 * * *$ & 1.000 & \\
\hline 16 Dispute Rate & $0.194 * * *$ & -0.031 & -0.025 & -0.001 & 0.058 & -0.077 & -0.013 & 1.000 \\
\hline 17 Female $\%$ & $-0.086^{*}$ & $-0.188 * * *$ & -0.006 & $-0.294 * * *$ & 0.070 & 0.078 & 0.003 & $-0.105^{*}$ \\
\hline 18 Ln Estab. Employment & $-0.067 *$ & $0.068^{*}$ & 0.017 & 0.028 & -0.012 & $-0.097 *$ & -0.074 & 0.010 \\
\hline 19 Branch & 0.034 & 0.002 & $0.077 *$ & $0.118 * * *$ & 0.014 & -0.091 & -0.089 & $0.123 *$ \\
\hline 20 Former Bell Company & -0.035 & $0.084^{*}$ & -0.038 & 0.088 & $-0.258 * * *$ & $-0.130 *$ & $-0.168 * * *$ & $0.106 *$ \\
\hline 21 HR Dept. on Premise & 0.063 & 0.005 & 0.022 & -0.050 & 0.044 & -0.047 & -0.042 & $0.013^{*}$ \\
\hline 22 College Graduates & -0.020 & -0.043 & 0.024 & $0.493 * * *$ & $0.097 *$ & 0.046 & 0.093 & $-0.106^{*}$ \\
\hline 23 Field Technicians & 0.027 & $0.215^{* * *}$ & -0.032 & 0.003 & -0.083 & -0.095 & -0.034 & 0.097 \\
\hline \multirow[t]{2}{*}{24 Office Technicians } & $0.074 *$ & -0.010 & 0.053 & $0.109 * * *$ & 0.006 & 0.023 & 0.025 & 0.085 \\
\hline & 17 & 18 & 19 & 20 & 21 & 22 & 23 & 24 \\
\hline 17 Female $\%$ & 1.000 & & & & & & & \\
\hline 18 Ln Estab. Employment & $0.085 *$ & 1.000 & & & & & & \\
\hline 19 Branch & 0.048 & $0.333 * * *$ & 1.000 & & & & & \\
\hline 20 Former Bell Company & 0.037 & $0.280 * * *$ & $0.288 * * *$ & 1.000 & & & & \\
\hline 21 HR Dept. on Premise & $0.138 * * *$ & $0.481 * * *$ & $0.192 * * *$ & 0.062 & 1.000 & & & \\
\hline 22 College Graduates & -0.042 & $-0.095^{*}$ & -0.063 & -0.043 & -0.026 & 1.000 & & \\
\hline 23 Field Technicians & $-0.576^{* * *}$ & $0.120 * * *$ & $0.105 * * *$ & $0.078^{*}$ & -0.042 & $-0.305^{* * *}$ & 1.000 & \\
\hline 24 Office Technicians & $-0.252 * * *$ & $-0.166 * * *$ & $-0.124 * * *$ & -0.031 & -0.058 & $0.079 *$ & $-0.277 * * *$ & 1.000 \\
\hline
\end{tabular}

*Statistically significant at the .10 level; **at the .05 level; ***at the .01 level.

cated on the left end of the distribution at zero (Maddala 1992) — no establishments, obviously, have fewer than zero annual quits. Tobit models correct for biasing in the coefficient estimates due to the truncation of the dependent variable; however, inter- pretation of the coefficients also is different under a Tobit model. McDonald and Moffit (1980) suggested a decomposition of the Tobit coefficients in to changes in the probability of observing an outcome above the left limit and changes in outcomes above 
the left limit. The second part of this decomposition represents the effect of changes in the independent variables on the dependent variable in the positive range, which provides an interpretation equivalent to OLS estimates for this range of outcomes once the appropriate calculation of the decomposition is made. ${ }^{2}$ Estimates of effect sizes reported here are based on this second part of the decomposition and provide an estimate of the expected change in the observed values of the dependent variable for a given change in an independent variable. Also, because quit rates are measured as a proportion of the current work force, the coefficients may be interpreted, once multiplied by 100 , as percentage point changes in the quit rate attributable to the given independent variable.

In the first Tobit equation in Table 3, we analyze the effects on quit rates of the three employee voice mechanisms. Union representation alone is associated with a reduction of 6.5 percentage points in the quit rate (Tobit 1 ), which drops to a 4.9 percentage point reduction in the quit rate in the full model (Tobit 4). Quit rates are 3.9 percentage points lower in establishments where the entire work force is in problemsolving groups than in establishments with no employees in problem-solving groups (Tobit 1 ), and are 3.6 percentage points lower in the full model (Tobit 4). Selfdirected teams are only significant at the $10 \%$ level in equation (1), but are significant at the $5 \%$ level in the full model, which indicates quit rates are 2.5 percentage points lower in establishments where the entire work force is organized into self-directed

${ }^{2}$ The adjustment based on the second term in the McDonald and Moffit (1980) decomposition is calculated by multiplying the Tobit coefficients by $\left[1-z * f(z) / F(z)-f(z)^{2} / F(z)^{2}\right]$, where $F(z)$ is the cumulative normal distribution function associated with the probability of cases being above the left limit; $f(z)$, the first derivative of $F(z)$, is the unit normal density associated with this probability; and $z$ is the corresponding $z$-score for this probability (see Roncek 1992). teams than in establishments with no employees in teams.

In the second equation (Tobit 2), we analyze the relationship between cost-cutting human resource practices and quit rates. Each of the five practices independently is associated with increased quit rates. An increase in the size of work force reductions equivalent to $1 \%$ of the current work force is associated with an increase of 1.4 percentage points in the quit rate, according to the results reported in equation (2); this association rises in the full model to a 3.5 percentage point increase in the quit rate. Increasing the proportion of parttimers by 10 percentage points is associated with a 0.9 percentage point (Tobit 2) or 1.1 percentage point (Tobit 4) rise in the quit rate for the core labor force. Increasing the proportion of temporary employees by 10 percentage points is associated with a 1.2 percentage point (Tobit 2) or 1.0 percentage point (Tobit 4) higher quit rate. Electronic monitoring of the work force at all times during the work day is associated with a 2.1 percentage point higher quit rate than for workers who are not electronically monitored (Tobit 4). Variable pay also is associated with higher quit rates at a barely significant $\alpha=0.10$ level in equation (2). In equation (4), however, it becomes significant at the $\alpha=0.01$ level and indicates that an increase in the portion of pay that is variable by 10 percentage points would raise the quit rate by 0.5 percentage points.

The third equation (Tobit 3) estimates the relationship between the three commitment-enhancing internal labor market variables and quit rates. Both internal mobility opportunities and a higher ratio of pay to the local cost of living significantly reduce quit rates. Training, by contrast, is not associated with any statistically significant difference in quits. If the portion of employees who have mobility opportunities within the organization increased by 10 percentage points, quit rates would be reduced in the range of 0.3 percentage points (Tobit 3) to 0.2 percentage points (Tobit $4)$. By increasing annual wages by $\$ 4,800$ (adjusted to reflect local cost of living), an establishment can reduce quit rates in the 
range of 0.6 percentage points (Tobit 3 ) to 0.4 percentage points (Tobit 4 ).

In each of the models, some controls are also statistically significant. Establishments that are larger are significantly more likely to have higher quit rates. With regard to occupational characteristics, field technicians and central office technicians are considerably less likely to quit than are call center workers in customer service and sales. Finally, once occupational and other characteristics are taken into account, the female composition of the work force becomes marginally significant and is negatively associated with quits.

In analyses not shown, we controlled for variation in industry segments (for example, wireline, wireless, and internet services). We also controlled for local labor markets, because prior research has shown that higher unemployment rates or alternative opportunities in the external market are negatively correlated with turnover (for example, Hulin et al. 1985; Carsten and Spector 1987; Gerhart 1990). For each establishment surveyed, we included the average 1998 unemployment rate for the county or city where the establishment is located, based on the Local Area Unemployment Statistics of the Bureau of Labor Statistics (http://stats.bls.gov.laumthd. $\mathrm{htm})$. However, we found that including these market measures had no statistically significant effect and lowered the variance explained, so we excluded them in our final analyses.

Turning to the nonunion dispute resolution mechanisms, we noted that in the full correlation matrix reported in Table 2, none of the variables representing nonunion dispute resolution procedures and dispute rates are significantly correlated with the quit rate. However, the full sample includes observations from both union and nonunion establishments. Therefore, we also investigated the possibility that establishments with nonunion arbitration and peer review procedures have higher quit rates than union establishments, but at the same time lower quit rates than nonunion establishments that lack these procedures. Using a subsample consisting of only the nonunion establishments, we found marginally significant negative correlations $(p$ $<.10$ ) between quit rates and the presence of nonunion arbitration procedures, peer review procedures, and the dispute rate. To further investigate the relationship between nonunion dispute resolution procedures and quit rates, we ran Tobit regressions for the quit rate on our dispute resolution variables, using the variables from the full model in Table 3 as control variables.

Table 4 presents the findings from Tobit regressions run on the subsample of respondents who answered the more detailed questions on dispute resolution procedures and activity. The focus of this analysis is on the question of whether there is evidence for lower quit rates for nonunion establishments that have dispute resolution procedures than for those lacking procedures. Equation (5) presents the results for the same variables as in the full model without any dispute resolution variables included to provide a basis for comparison. The smaller sample size used here reduces the significance levels for some variables, but the coefficient estimates in equation (5) are generally similar to those for the full sample, supporting the representativeness of the subsample when compared to the full sample.

In each of the other models in Table 4, the quit rate is regressed on a series of combinations of dispute resolution variables added to the set of independent variables from the full model presented in Table 3. In each of these models, the procedure usage rate is included along with the dummy variables representing the type of dispute resolution procedure, so that we are simultaneously accounting for the effects of the presence and usage of procedures on quit rates. The only dispute resolution procedure type variable that reaches conventional levels of statistical significance in Table 4 is the variable representing the presence of peer review procedures. Neither the presence of any type of nonunion procedure nor the inclusion of nonunion arbitration procedures has a statistically significant association with the quit rate in 
Table 3. Predictors of Annual Quit Rates.

\begin{tabular}{|c|c|c|c|c|}
\hline Variable & Tobit 1 & Tobit 2 & Tobit 3 & Tobit 4 \\
\hline \multicolumn{5}{|l|}{ Employee Voice } \\
\hline Union & $\begin{array}{l}-0.152^{* * * * *} \\
0.027\end{array}$ & & & $\begin{array}{l}-0.114^{* * * * *} \\
0.026\end{array}$ \\
\hline Problem-Solving Groups \% & $\begin{array}{l}-0.092 * * * \\
0.023\end{array}$ & & & $\begin{array}{l}-0.084 * * * \\
0.024\end{array}$ \\
\hline Self-Directed Teams \% & $\begin{array}{c}-0.049 * \\
0.026\end{array}$ & & & $\begin{array}{c}-0.058 * * \\
0.028\end{array}$ \\
\hline \multicolumn{5}{|l|}{ Cost-Cutting HR Practices } \\
\hline Downsizing in Last Five Years & & $\begin{array}{l}3.267 * * * * \\
0.687\end{array}$ & & $\begin{array}{l}8.088 * * * * \\
2.309\end{array}$ \\
\hline Part-Time Workers \% & & $\begin{array}{l}0.212 * * * \\
0.074\end{array}$ & & $\begin{array}{l}0.251 * * * \\
0.079\end{array}$ \\
\hline Temporary Workers \% & & $\begin{array}{l}0.281 * * * * \\
0.058\end{array}$ & & $\begin{array}{l}0.236 * * * * \\
0.059\end{array}$ \\
\hline Electronic Monitoring \% & & $\begin{array}{l}0.047 * * \\
0.022\end{array}$ & & $\begin{array}{l}0.050 * * \\
0.023\end{array}$ \\
\hline Variable Pay & & $\begin{array}{l}0.066^{*} \\
0.036\end{array}$ & & $\begin{array}{l}0.107 * * * \\
0.036\end{array}$ \\
\hline \multicolumn{5}{|c|}{ Commitment-Enhancing HR Practices } \\
\hline Mobility $\%$ & & & $\begin{array}{l}-0.073 * * * \\
0.026\end{array}$ & $\begin{array}{c}-0.040^{*} \\
0.023\end{array}$ \\
\hline Training & & & $\begin{array}{r}-0.006 \\
0.006\end{array}$ & $\begin{array}{r}-0.005 \\
0.005\end{array}$ \\
\hline Pay to Local Cost of Living & & & $\begin{array}{l}-0.152 * * * \\
0.034\end{array}$ & $\begin{array}{l}-0.102 * * * \\
0.033\end{array}$ \\
\hline \multicolumn{5}{|l|}{ Control Variables } \\
\hline Female \% & $\begin{array}{r}-0.026 \\
0.036\end{array}$ & $\begin{array}{r}-0.030 \\
0.036\end{array}$ & $\begin{array}{c}-0.071 * \\
0.040\end{array}$ & $\begin{array}{c}-0.067 * \\
0.037\end{array}$ \\
\hline Ln of Estab. Employment & $\begin{array}{l}0.0130 * * \\
0.007\end{array}$ & $\begin{array}{l}0.016^{* *} \\
0.007\end{array}$ & $\begin{array}{l}0.010 \\
0.007\end{array}$ & $\begin{array}{l}0.020 * * * \\
0.007\end{array}$ \\
\hline Branch & $\begin{array}{l}0.025 \\
0.023\end{array}$ & $\begin{array}{l}0.033 \\
0.023\end{array}$ & $\begin{array}{l}0.051 \\
0.025\end{array}$ & $\begin{array}{l}0.022 \\
0.024\end{array}$ \\
\hline Former Bell Company & $\begin{array}{l}0.014 \\
0.024\end{array}$ & $\begin{array}{c}-0.034 * \\
0.020\end{array}$ & $\begin{array}{r}-0.027 \\
0.022\end{array}$ & $\begin{array}{l}0.017 \\
0.023\end{array}$ \\
\hline Human Resource Department & $\begin{array}{l}0.046^{* *} \\
0.019\end{array}$ & $\begin{array}{l}0.017 \\
0.020\end{array}$ & $\begin{array}{l}0.037^{*} \\
0.021\end{array}$ & $\begin{array}{l}0.025 \\
0.020\end{array}$ \\
\hline College Graduates & $\begin{array}{r}-0.011 \\
0.023\end{array}$ & $\begin{array}{l}0.009 \\
0.024\end{array}$ & $\begin{array}{l}0.059 * * \\
0.028\end{array}$ & $\begin{array}{l}0.035 \\
0.027\end{array}$ \\
\hline Field Technicians & $\begin{array}{l}-0.121 \text { **** } \\
0.031\end{array}$ & $\begin{array}{l}-0.134 * * * * \\
0.032\end{array}$ & $\begin{array}{l}-0.148^{* * * * *} \\
0.034\end{array}$ & $\begin{array}{l}-0.111 \text { **** } \\
0.032\end{array}$ \\
\hline Office Technicians & $\begin{array}{l}-0.063 * * \\
0.028\end{array}$ & $\begin{array}{l}-0.066^{* *} \\
0.029\end{array}$ & $\begin{array}{l}-0.078^{* * *} \\
0.031\end{array}$ & $\begin{array}{r}-0.040 \\
0.029\end{array}$ \\
\hline Constant & $\begin{array}{l}0.105^{* * *} \\
0.039\end{array}$ & $\begin{array}{r}-0.024 \\
0.040\end{array}$ & $\begin{array}{l}0.199 * * * * \\
0.046\end{array}$ & $\begin{array}{l}0.124 * * * \\
0.048\end{array}$ \\
\hline Observations & 576 & 545 & 521 & 492 \\
\hline Likelihood Ratio Chi Square & 113.150 & 124.560 & 84.340 & 173.120 \\
\hline Pseudo R Squared & 0.674 & 0.767 & 0.509 & 1.303 \\
\hline Likelihood Ratio & $-27.3 / 4149$ & $-18.91 / 1291$ & $-40.62 / 8212$ & $20 / 1309$ \\
\hline
\end{tabular}

\footnotetext{
$*$ Statistically significant at the .10 level; **at the .05 level; ***at the .01 level; ****at the .001 level.
} 
Table 4. Dispute Resolution and Quit Rates.

\begin{tabular}{|c|c|c|c|c|c|}
\hline Variable & Tobit 5 & Tobit 6 & Tobit 7 & Tobit 8 & Tobit 9 \\
\hline \multicolumn{6}{|l|}{ Employee Voice } \\
\hline Any Nonunion Procedure & & $\begin{array}{r}-0.028 \\
0.027\end{array}$ & & & $\begin{array}{r}-0.011 \\
0.028\end{array}$ \\
\hline Nonunion Arbitration & & & $\begin{array}{r}-0.026 \\
0.033\end{array}$ & & $\begin{array}{r}-0.012 \\
0.035\end{array}$ \\
\hline Peer Review & & & & $\begin{array}{c}-0.059^{*} \\
0.033\end{array}$ & $\begin{array}{r}-0.047 \\
0.037\end{array}$ \\
\hline Annual Dispute Rate & & $\begin{array}{l}0.139 * * \\
0.057\end{array}$ & $\begin{array}{l}0.129 * * \\
0.056\end{array}$ & $\begin{array}{l}0.138^{* *} \\
0.056\end{array}$ & $\begin{array}{l}0.142 * * \\
0.057\end{array}$ \\
\hline Union & $\begin{array}{l}-0.110^{* * * *} \\
0.034\end{array}$ & $\begin{array}{l}-0.133^{* * * * *} \\
0.040\end{array}$ & $\begin{array}{l}-0.125^{* * * *} \\
0.037\end{array}$ & $\begin{array}{l}-0.128^{* * * *} \\
0.036\end{array}$ & $\begin{array}{l}-0.140 \text { **** } \\
0.041\end{array}$ \\
\hline Problem-Solving Groups \% & $\begin{array}{r}-0.028 \\
0.031\end{array}$ & $\begin{array}{r}-0.042 \\
0.032\end{array}$ & $\begin{array}{r}-0.042 \\
0.032\end{array}$ & $\begin{array}{r}-0.040 \\
0.032\end{array}$ & $\begin{array}{r}-0.043 \\
0.033\end{array}$ \\
\hline Self-Directed Teams \% & $\begin{array}{r}-0.031 \\
0.035\end{array}$ & $\begin{array}{r}-0.022 \\
0.035\end{array}$ & $\begin{array}{r}-0.015 \\
0.036\end{array}$ & $\begin{array}{r}-0.012 \\
0.036\end{array}$ & $\begin{array}{r}-0.008 \\
0.037\end{array}$ \\
\hline \multicolumn{6}{|l|}{ Cost-Cutting HR Practices } \\
\hline Downsizing in Last Five Years & $\begin{array}{l}7.19 * * * \\
2.24\end{array}$ & $\begin{array}{l}7.32 * * * \\
2.38\end{array}$ & $\begin{array}{l}7.25^{* * * *} \\
2.42\end{array}$ & $\begin{array}{l}7.37 * * * \\
2.38\end{array}$ & $\begin{array}{l}7.20 * * * \\
2.42\end{array}$ \\
\hline Part-Time Workers \% & $\begin{array}{l}0.071 \\
0.118\end{array}$ & $\begin{array}{l}0.091 \\
0.118\end{array}$ & $\begin{array}{l}0.050 \\
0.128\end{array}$ & $\begin{array}{l}0.089 \\
0.118\end{array}$ & $\begin{array}{l}0.052 \\
0.129\end{array}$ \\
\hline Temporary Workers \% & $\begin{array}{l}0.248^{* * * *} \\
0.079\end{array}$ & $\begin{array}{l}0.221 * * * \\
0.080\end{array}$ & $\begin{array}{l}0.228^{* * *} \\
0.082\end{array}$ & $\begin{array}{l}0.207 * * \\
0.081\end{array}$ & $\begin{array}{l}0.214 * * * \\
0.082\end{array}$ \\
\hline Electronic Monitoring \% & $\begin{array}{l}0.028 \\
0.029\end{array}$ & $\begin{array}{l}0.032 \\
0.029\end{array}$ & $\begin{array}{l}0.030 \\
0.030\end{array}$ & $\begin{array}{l}0.035 \\
0.030\end{array}$ & $\begin{array}{l}0.034 \\
0.030\end{array}$ \\
\hline Variable Pay & $\begin{array}{l}0.147 * * * \\
0.054\end{array}$ & $\begin{array}{l}0.157 * * * \\
0.055\end{array}$ & $\begin{array}{l}0.161^{* * *} \\
0.055\end{array}$ & $\begin{array}{l}0.164 * * * \\
0.056\end{array}$ & $\begin{array}{l}0.158^{* * * *} \\
0.057\end{array}$ \\
\hline \multicolumn{6}{|c|}{ Commitment-Enhancing HR Practices } \\
\hline Mobility \% & $\begin{array}{r}-0.035 \\
0.031\end{array}$ & $\begin{array}{r}-0.025 \\
0.032\end{array}$ & $\begin{array}{r}-0.027 \\
0.032\end{array}$ & $\begin{array}{r}-0.027 \\
0.032\end{array}$ & $\begin{array}{r}-0.026 \\
0.033\end{array}$ \\
\hline Training & $\begin{array}{r}-0.007 \\
0.007\end{array}$ & $\begin{array}{r}-0.007 \\
0.007\end{array}$ & $\begin{array}{r}-0.006 \\
0.007\end{array}$ & $\begin{array}{r}-0.006 \\
0.007\end{array}$ & $\begin{array}{r}-0.006 \\
0.007\end{array}$ \\
\hline Pay to Local Cost of Living & $\begin{array}{l}-0.105^{* *} \\
0.044\end{array}$ & $\begin{array}{l}-0.103^{* *} \\
0.045\end{array}$ & $\begin{array}{l}-0.100^{* *} \\
0.046\end{array}$ & $\begin{array}{l}-0.102^{* *} \\
0.045\end{array}$ & $\begin{array}{l}-0.097 * * \\
0.046\end{array}$ \\
\hline \multicolumn{6}{|l|}{ Control Variables } \\
\hline $\begin{array}{l}\text { Observations } \\
\text { Likelihood Ratio Chi Square } \\
\text { Pseudo R Squared } \\
\text {-2 Log Likelihood }\end{array}$ & $\begin{array}{c}253 \\
110.99 \\
1.732 \\
-46.907\end{array}$ & $\begin{array}{c}243 \\
112.75 \\
1.809 \\
-50.425\end{array}$ & $\begin{array}{c}238 \\
107.45 \\
1.707 \\
-44.490\end{array}$ & $\begin{array}{c}241 \\
113.45 \\
1.757 \\
-48.875\end{array}$ & $\begin{array}{c}237 \\
108.82 \\
1.705 \\
-45.012\end{array}$ \\
\hline
\end{tabular}

*Statistically significant at the .10 level; **at the .05 level; ***at the .01 level; ****at the .001 level.

any of the specifications in which they are included. Even in the case of peer review procedures, significance is achieved only at the $p<.10$ level in equation (8).

Thus we do not find strong evidence that nonunion dispute resolution procedures provide voice mechanisms that reduce quit rates in comparison to establishments lack- ing such procedures. Higher dispute rates, however, are significantly associated with higher quit rates at the $\mathrm{p}<.05$ level in all specifications. As discussed earlier, previous research on unionized workplaces linked high grievance rates to heightened levels of conflict and reduced organizational performance (Katz, Kochan, and 
Gobeille 1983; Katz, Kochan, and Weber 1985; Norsworthy and Zabala 1986; Ichniowski 1986; Cutcher-Gershenfeld 1991). This result supports that finding by linking high dispute rates to higher quit rates and extends it to include both nonunion and union workplaces.

\section{Discussion}

Our results indicate that union institutions and managerial policies that facilitate voice can significantly reduce exits. Unions have a strong influence on quit rates, despite significant declines in union density in this industry-from roughly two-thirds of all employees in 1984 to one-third in 1998. The inverse relationship between unions and quit rates is statistically significant even after we control for team-based voice mechanisms, pay, and other human resource practices that are affected by collective bargaining. These findings are in contrast to those of Delery et al. (2000), who found that the union effect on turnover in the trucking industry disappeared when wages and benefits were taken into account. Participation in problem-solving teams is negatively related to quit rates; and participation in self-directed teams has a smaller effect. Union representation and direct participation via shop-floor teams may be viewed as complementary vehicles for employee voice at work. By contrast, we found that nonunion dispute resolution procedures, in some cases designed as an alternative to union grievance procedures, did not significantly reduce quit rates. If new workplace dispute resolution procedures are going to help close the representation gap in nonunion workplaces, our results suggest they will need to be something stronger than the present employerdesigned procedures.

It is useful to discuss the findings for nonunion dispute procedures in the context of the telecommunications industry, which despite the decline in union density remains more highly unionized than most other industries in the country. Prior research suggests that firms adopt dispute resolution procedures as a union avoid- ance strategy (Colvin 1999). To the degree that this is true, we would expect nonunion dispute resolution procedures to be particularly strong in this industry because the threat of union organizing is high. In addition, we examined stronger forms of nonunion procedures, including nonunion arbitration and peer review panels. Even with this relatively favorable setting for nonunion procedures, we found no statistically significant results for nonunion arbitration procedures and only marginally significant results for peer review procedures, which were not robust with respect to alternative specifications of the model.

One alternative explanation is that management may introduce some nonunion procedures in response to high levels of employee complaints in the workplace. If these complaints reflect high levels of workplace conflict that are also associated with higher quit rates, we might have an effect in the opposite direction, reducing any negative relationship between procedure presence and quit rates. Although we cannot definitively exclude the possibility of this reverse mechanism, our inclusion of the dispute rate in all of the dispute resolution equations helps control for the possibility that some of the procedures were introduced in response to high levels of workplace conflict.

Finally, our results are strong and consistent on the question of the relationship between grievance rates and quit rates: holding the type of procedure constant, we find a positive relationship. This result is consistent with the findings of Lewin and colleagues in union settings and indicates that future research on dispute resolution procedures needs to disaggregate the effects of the presence of dispute resolution procedures and the usage of those same procedures. One should not make the mistake of assuming that because the availability of voice mechanisms in the workplace is associated with lower quit rates, increased usage of these voice mechanisms will be associated with lower quit rates; indeed, our results suggest that the reverse is true.

With respect to human resource prac- 
tices, our results show that internal mobility opportunities and higher wages are associated with lower quit rates, but costcutting human resource practices that treat labor as a variable cost and introduce labor market competition into the workplace are associated with higher employee quits. Downsizing, contingent staffing, electronic monitoring, and variable pay are significantly associated with higher quit rates. Ongoing downsizing creates uncertainty and demoralization that often lead the most qualified to obtain jobs elsewhere. Higher use of temporary workers may signal to core employees that the employer has a ready supply of substitute workers and is not committed to long-term employment contracts. Greater reliance on electronic monitoring also significantly drives employee quits because it signals mistrust and creates more onerous working conditions. Call center employees experience electronic monitoring as unremitting surveillance of their work and personal activities, including their use of the restroom. Where possible, they are likely to seek alternative working conditions.

With respect to variable pay, some research on high performance work systems finds that variable pay clusters with teams and investment in training in a bundle of coherent practices. By contrast, our results indicate that variable pay plans are exit drivers. One explanation for these contradictory findings is that in most of the high performance literature, performance-based pay is in the form of group incentives such as gain-sharing or profit-sharing that are added to base pay and that rarely exceed $5-$ $10 \%$ of total pay. In our case, more than half of variable pay is individual commission pay for service and sales workers, and the mean percent of pay at risk is $27 \%$ (with a range of variation between $0 \%$ and $100 \%$ ).

Commissions are a type of piece rate system whereby employees are directly compensated for each item they sell. While some workers may thrive on risk and individual competition and benefit through higher earnings under these plans, prior research suggests that most workers are risk-averse. Because most do not have di- versified portfolios, they are likely to be dissatisfied with the greater risk and earnings volatility that are associated with variable pay. In addition, prior research shows that piece rate systems are structured as prisoner dilemma games (see, for example, Levine 1992 or Gillespie 1991). That is, as employees learn how to make more pieces to increase their earnings, they often adjust the piece rate to capture the gains in productivity. This dynamic of employees improving performance leading to rate reductions is well documented. It causes employees to game the system to "make out." Under piece rate systems, gaming the pay plan often became more important to workers than getting the job done (Roy 1952; Burawoy 1979). To defeat the game of making out, management often makes the incentive plan more complex, but the game continues under the new more elaborate rules. Peer pressure restrains high performers because high performance may increase an individual's earnings, but only temporarily. In the longer run, high performance leads to rate reductions, which disadvantage all employees-hence the prisoner dilemma quality of piece rates and commissions.

There are also reasons to question whether commission pay in service and sales environments improves organizational performance. On the one hand, commissions provide incentives to individuals to sell more. On the other hand, shirking under these plans takes the form of a tendency for the quality of the service to fall (Pencavel 1977). In field research for this study, for example, sales reps reported that they tried to close a sale to get their commission even when customers said they would probably drop the feature after the promotion ended. Sales reps also reported knowingly selling to customers who had been recently disconnected for failure to pay their bills. In addition, individual commission plans undermine the social organization of work and discourage participation in direct voice mechanisms such as teams, decreasing joint problem-solving and sharing of knowledge and information. Recent research in call centers, for example, has shown that both 
service quality and sales are higher where work organization and group incentives emphasize team work (Batt 1999; Moynihan and Batt 2000). Thus, there is reason to believe that individual commission plans not only raise quit rates but also are detrimental to service and sales performance because they undermine group problemsolving and shared expertise. While variable pay plans are often adopted because of the intuitive appeal of paying-for-performance, we need more research to understand how different types of plans affect worker quit rates, the social organization of work, and organizational performance.

Gender differences also merit some discussion. Once occupational and human resource practices are taken into account, the female composition of the work force is associated with lower quit rates (at a marginally statistically significant level). This is consistent with the prior literature as well as our field research. Occupational segregation is widespread in this industry, with women concentrated in the jobs with low discretion, continuous monitoring, and low pay. In our sample, women comprise 56\% of customer service and sales jobs but only $12 \%$ of technical jobs. Within call centers, they are concentrated in operator services $(80 \%)$ and the residential mass market $(60 \%)$. By contrast, service and sales reps serving business clientele are 55\% male. Thus, it is women's concentration in lower occupational titles, rather than gender per se, that is associated with higher quit rates. Once occupational differences are taken into account, women have lower quit rates than men.

\section{Limitations and Conclusions}

There are several limitations to this study. Because the data were collected at the establishment unit of analysis, it was not possible to obtain the kind of individual-level data that capture variation in human capital characteristics or in the use of human resource and dispute resolution procedures within the establishment. Moreover, the cross-sectional nature of the data limits causal inferences. It could be, for example, that high unemployment in some localities reduces the likelihood of quits, thereby allowing the adoption of work innovations such as teams because managers know that the work force is experienced and stable. Using unemployment data from the $\mathrm{Bu}-$ reau of Labor Statistics for each county where an establishment was located, we explored this explanation in analyses not shown, and found no statistically significant correlation between local unemployment and adoption of HR practices. These analyses suggest that at least in this industry, adoption is not driven by labor market conditions.

We believe that our approach to the question of aggregate quit rates is promising for a number of reasons. Our findings suggest that it is important to disaggregate the differential influences of alternative voice mechanisms and human resource practices on employee quit rates because they do not appear to have a consistent or coherent effect. Quit rates are substantially lower in unionized workplaces than in nonunion workplaces even in the presence of a broad set of controls for compensation and a range of human resource practices. In addition, both self-directed teams and off-line problem-solving groups have strong and statistically significant negative relationships with quit rates, lending support to the idea that these mechanisms for direct participation can provide employees with enhanced voice in the workplace. In contrast, the absence of consistent statistically significant results for nonunion dispute resolution procedures suggests the need for further examination of the question of what features need to be incorporated into procedures in order to ensure that they can serve as effective voice mechanisms that provide employees with alternatives to quitting. In addition, differences in the results for nonunion arbitration and peer review panels provide support for distinguishing between different types of nonunion procedure in future research. Put simply, results based on research on one type of nonunion procedure may not hold for other types of procedures. Among different types of procedures, peer review 
panels have received very little attention in academic research, and our results suggest the need for further investigation of their role in the nonunion workplace. Our results also support recommendations (for example, Lewin 1999) that have been made for including measures of both the presence and usage of procedures in future research. Whereas the presence of peer review procedures had a marginally significant negative association with quit rates, greater usage of procedures had a consistent and statistically significant positive association with higher quit rates. This suggests that it is important to treat availability and usage of procedures as conceptually distinct phenomena.

While this research is based on the telecommunications services industry, we believe the findings have broader implications. In the U.S. context, cost-cutting human resource practices diffused during a period from the late 1970 s to the mid1990s when labor supply exceeded demand, real wages of workers were declining, and workers had few labor market alternatives. These HR practices disrupted the relatively stable internal labor market practices in large firms that were developed during two periods of full employment-World War I through the 1920s, and World War II through the 1970s. In the tight labor markets of the 1990s and after, however, highly trained employees found it relatively easy to find comparable jobs in related industries. Firms may be losing the more qualified workers and may find it necessary to return to the kinds of commitment-enhancing or internal labor market practices that firms developed in prior periods of full employment. At times of near-full employment, quit rates may be the critical factor raising operating costs and preventing organizations from achieving their performance objectives, as is suggested by recent research that shows an inverse relationship between quit rates and organizational performance. In a near-full-employment economy, employers who have retained internal labor market practices and employee voice mechanisms may have a competitive cost and performance advantage over those who use cost-cutting human resource practices.

\section{REFERENCES}

Alexander, Jeffrey A., Joan R. Bloom, and Beverly A. Nuchols. 1994. "Nursing Turnover and Hospital Efficiency: An Organization Level Analysis." Industrial Relations, Vol. 33, No. 4 (October), pp. 505-20. Appelbaum, Eileen, Thomas Bailey, Peter Berg, and Arne Kalleberg. 2000. Manufacturing Advantage: Why High Performance Work Systems Pay Off. Ithaca, N.Y.: ILR Press (an imprint of Cornell University Press).

Arthur, Jeffrey. 1994. "Effects of Human Resource Systems on Manufacturing Performance and Turnover." Academy of Management Journal, Vol. 37, No. 3 (June), pp. 670-87.

Batt, Rosemary. 1999. "Work Organization, Technology, and Performance in Customer Service and Sales." Industrial and Labor Relations Review, Vol. 52, No. 4 (July), pp. 539-64.

Bemmels, Brian. 1997. "Exit, Voice, and Loyalty in Employment Relationships." In David Lewin, Daniel J.B. Mitchell, and Mahmood A. Zaidi, eds., The Human Resource Management Handbook, Part II. Greenwich, Conn.: JAI Press, pp. 245-59.

Bennett, Nathan, Terry C. Blum, Rebecca G. Long, and Paul M. Roman. 1993. "A Firm Level Analysis of Employee Attrition." Group and Organization Management, Vol. 18, No. 4, pp. 482-99.

Boroff, Karen E., and David Lewin. 1997. "Loyalty, Voice, and Intent to Exit a Union Firm: A Conceptual and Empirical Analysis." Industrial and Labor Relations Review, Vol. 51, No. 1 (October), pp. 5063.

Burawoy, Michael. 1979. Manufacturing Consent: Changes in the Labor Process under Monopoly Capitalism. Chicago: University of Chicago Press.

Cappelli, Peter. 1999. The New Deal at Work. Cambridge, Mass.: Harvard Business School Press.

Cappelli, Peter, and Keith Chauvin. 1991. "A Test of an Efficiency Model of Grievance Activity." Industrial and Labor Relations Review, Vol. 45, No. 1 (October), pp. 3-14.

Carayon, Pascale. 1993. "Effect of Electronic Performance Monitoring on Job Design and Worker Stress: Review of the Literature and Conceptual Model." Human Factors, Vol. 35, No. 3, pp. 385-95.

Carsten, Jeanne M., and Paul E. Spector. 1987. "Unemployment, Job Satisfaction, and Employee Turnover." Journal of Applied Psychology, Vol. 72, No. 3 (June), pp. 374-81. 
Cohen, Susan, and Diane Bailey. 1997. "What Makes Teams Work: Group Effectiveness Research from the Shop Floor to the Executive Suite." Journal of Management, Vol. 23, No. 3 (June), pp. 239-90.

Colvin, Alexander J.S. 1999. Citizens and Citadels: Dispute Resolution and the Governance of Employment Relations. Diss., Cornell University.

Cordery, John L., Walter S. Mueller, and Leigh M. Smith. 1991. "Attitudinal and Behavioral Effects of Autonomous Group Working: A Longitudinal Field Study." Academy of Management Journal, Vol. 34, No. 2 (June), pp. 464-76.

Cotton, John L. 1993. Employee Involvement: Methods for Improving Performance and Work Attitudes. Newbury Park, Calif.: Sage.

Cotton, John L., and Jeffrey M. Tuttle. 1986. "Employee Turnover: A Meta-Analysis and Review with Implications for Research." Academy of Management Review, Vol. 11, No. 1 (January), pp. 55-70.

Cutcher-Gershenfeld, Joel. 1991. "The Impact on Economic Performance of a Transformation in Workplace Relations." Industrial and Labor Relations Review, Vol. 44, No. 2 (January), pp. 241-60.

Delery, John, Nina Gupta, Jason Shaw, G. Douglas Jenkins, and Margot Ganster. 2000. "Unionization, Compensation, and Voice Effects on Quits and Retention." Industrial Relations, Vol. 39, No. 4 (October), pp. 625-46.

Doeringer, Peter B., and Michael J. Piore. 1971. Internal Labor Markets and Manpower Analysis. Lexington, Mass.: Heath.

Ewing, David W. 1989. Justice on the Job: Resolving Grievances in the Nonunion Workplace. Boston: Harvard Business School Press.

Feuille, Peter, and John T. Delaney. 1992. "The Individual Pursuit of Organizational Justice: Grievance Procedures in Nonunion Workplaces." Research in Personnel and Human Resources Management, Vol. 10, pp. 187-232.

Freeman, Richard B. 1980a. "The Exit-Voice Tradeoff in the Labor Market: Unionism, Job Tenure, Quits, and Separations." Quarterly Journal of Economics, Vol. 94, No. 3 (August), pp. 643-73.

.1980b. "Unionism and the Dispersion of Wages." Industrial and Labor Relations Review, Vol. 34, No. 1 (October), pp. 3-23.

1982. "Union Wage Practices and Wage Dispersion within Establishments." Industrial and Labor Relations Review, Vol. 36, No. 1 (October), pp. 3-20.

Freeman, Richard B., and James L. Medoff. 1984. What Do Unions Do? New York: Basic Books.

Gerhart, Barry. 1990. "Voluntary Turnover and Alternative Job Opportunities." Journal of Applied Psychology, Vol. 75, pp. 467-73.

1999. "Human Resource Management and Firm Performance: Challenges in Making Causal Inferences." In Patrick Wright, Lee Dyer, John Boudreau, and George Milkovich, eds., Research in Personnel and Human Resources Management: Strategic HRM in the 21st Century (Supplement 4). Greenwich, Conn: JAI Press.

Gillespie, Richard. 1991. Manufacturing Knowledge: A History of the Hawthorne Experiments. Cambridge:
Cambridge University Press.

Hackman, J. Richard, and Greg R. Oldham. 1980. Work Redesign. Reading, Mass.: Addison-Wesley. Hirschman, Albert O. 1970. Exit, Voice, and Loyalty. Cambridge, Mass.: Harvard University Press.

Hom, Peter W., and Rodger W. Griffeth. 1995. Employee Turnover. Cincinnati: South-Western College Publishing.

Houseman, Susan. 2001. "Why Employers Use Flexible Staffing Arrangements: Evidence from an Establishment Survey." Industrial and Labor Relations Review, Vol. 55, No. 1 (October), pp. 149-70.

Hulin, Charles L., Mary A. Roznowski, and Donna Hachiya. 1985. "Alternative Opportunities and Withdrawal Decisions: Empirical and Theoretical Discrepancies and an Integration." Psychological Bulletin, Vol. 97, No. 2, pp. 233-50.

Huselid, Mark A. 1996. "The Impact of Human Resource Management Practices on Turnover, Productivity, and Corporate Financial Performance." Academy of Management Journal, Vol. 38, No. 3 (June), pp. 635-72.

Ichniowski, Casey. 1986. "The Effects of Grievance Activity on Productivity." Industrial and Labor Relations Review, Vol. 40, No. 1 (October), pp. 75-89.

Ichniowski, Casey, Thomas Kochan, David Levine, Craig Olson, and George Strauss. 1996. "What Works at Work: Overview and Assessment." Industrial Relations, Vol. 35, No. 3 (July), pp. 299-334.

Jackson, Susan E., Randall S. Schuler, and J. Carlso Rivero. 1989. "Organizational Characteristics as Predictors of Personnel Practices." Personnel Psychology, Vol. 42, pp. 727-86.

Jacoby, Sanford. 1985. Employing Bureaucracy. New York: Columbia University Press.

Katz, Harry C., Thomas A. Kochan, and Kenneth R. Gobeille. 1983. "Industrial Relations Performance, Economic Performance, and QWL Programs: An Interplant Analysis." Industrial and Labor Relations Review, Vol. 37, No. 1 (October), pp. 3-17.

Katz, Harry C., Thomas A. Kochan, and Mark R. Weber. 1985. "Assessing the Effects of Industrial Relations and Quality of Work Life Efforts on Organizational Effectiveness." Academy of Management Journal, Vol. 28, No. 3 (September), pp. 509-27.

Katz, Lawrence F., and Alan B. Krueger. 1999. "The High Pressure U.S. Labor Market of the 1990s." Brookings Papers on Economic Activity, Vol. 1, No. 1, pp. 1-65.

Leonard, Jonathan S. 1987. "Carrots and Sticks: Pay, Supervision, and Turnover." Journal of Labor Economics, Vol. 5, No. 4, Part 2 (October), pp. S136-52.

Levine, David. 1992. "Piece Rate, Output Restriction, and Conformism." Journal of Economic Psychology, Vol. 13, pp. 473-89.

Levine, David, and Laura D'Andrea Tyson. 1990. "Participation, Productivity, and the Firm's Environment." In Alan Blinder, ed., Paying for Productivity. Washington, D.C.: Brookings Institution.

Lewin, David. 1987. "Dispute Resolution in the Nonunion Firm: A Theoretical and Empirical Analysis." Journal of Conflict Resolution, Vol. 31, No. 3 (September), pp. 465-502. 
1990. "Grievance Procedures in Nonunion Workplaces: An Empirical Analysis of Usage, Dynamics, and Outcomes." Chicago-Kent Law Review, Vol. 66, No. 3, pp. 823-44.

1999. "Theoretical and Empirical Research on the Grievance Procedure and Arbitration: A Critical Review." Chapter 5 in Adrienne E. Eaton and Jeffery H. Keefe, eds., Employment Dispute Resolution and Worker Rights in the Changing Workplace. Madison, Wis.: Industrial Relations Research Association.

Lewin, David, and Karen Boroff. 1996. "The Role of Loyalty in Exit and Voice: A Conceptual and Empirical Analysis.” In David Lewin, Bruce E. Kaufman, and Donna Sockell, eds., Advances in Industrial and Labor Relations, Vol. 7. Greenwich, Conn.: JAI Press, pp. 69-96.

Lewin, David, and Richard Peterson. 1999. "Behavioral Outcomes of Grievance Activity." Industrial Relations, Vol. 38, No. 4 (October), pp. 554-76.

Lincoln, James R., and Arne L. Kalleberg. 1996. "Commitment, Quits, and Work Organization in Japanese and U.S. Plants." Industrial and Labor Relations Review, Vol. 50, No. 1 (October), pp. 3959.

Maddala, G. S. 1992. Introduction to Econometrics, 2nd ed. New York: Macmillan.

McEnvoy, G. M., and Wayne F. Cascio. 1985. "Strategies for Reducing Employee Turnover: A MetaAnalysis." Journal of Applied Psychology, Vol. 70, No. 3 (June), pp. 342-53.

Miller, Paul, and Charles Mulvey. 1991. "Australian Evidence on the Exit/Voice Model of the Labor Market." Industrial and Labor Relations Review, Vol. 45, No. 1 (October), pp. 44-57.

Moynihan, Lisa, and Rosemary Batt. 2000. "Antecedents and Consequences of Transactive Memory in Service Teams: Theory and Scale Development." Paper presented at the Academy of Management Meetings, Toronto, Ontario, August 6-9.

Norsworthy, J. R., and Craig A. Zabala. 1985. "Worker Attitudes, Worker Behavior, and Productivity in the U.S. Automobile Industry, 1959-76." Industrial and Labor Relations Review, Vol. 38, No. 4 (July), pp. 54457.

Oi, Walter. 1962. "Labor as a Quasi-Fixed Factor." Journal of Political Economy, Vol. 70, No. 6 (December), pp. 538-55.

Osterman, Paul. 1987. "Turnover, Employment Security, and the Performance of the Firm." In Morris Kleiner, Myron Roomkin, and Sidney W. Salsburg, eds., Human Resources and the Performance of the Firm. IRRA Series. Madison, Wis.: Industrial Relations Research Association.

1994a. "How Common Is Workplace Transformation and Who Adopts It?" Industrial and Labor Relations Review, Vol. 47, No. 2 (January), pp. 17388.

1994b. "Internal Labor Markets: Theory and Change." In Clark Kerr and Paul Staudohar, eds., Labor Economics and Industrial Relations: Markets and Institutions. Cambridge, Mass.: Harvard University Press, pp. 303-39.

1999. Securing Prosperity. Princeton: Princeton
University Press.

Park, Hong Y., Joseph Ofori-Dankwa, and Deborah Ramirez Bishop. 1994. "Organizational and Environmental Determinants of Functional and Dysfunctional Turnover: Practical and Research Implications." Human Relations, Vol. 47 (May), pp. 353366.

Pencavel, John H. 1977. "Work Effort, On-the-Job Screening, and Alternative Methods of Remuneration.” In Ronald Ehrenberg, ed., Research in Labor Economics, Vol. 1. Greenwich, Conn.: JAI Press, pp. 225-58.

Powell, Irene, Mark Montgomery, and James Cosgrove. 1994. "Compensation Structure and Establishment Quit and Fire Rates." Industrial Relations, Vol. 33, No. 2, pp. 229-48.

Rebitzer, James B. 1986. "Establishment Size and Job Tenure." Industrial Relations, Vol. 25, No. 3 (July), pp. 292-302.

Rees, Daniel, I. 1991. "Grievance Procedure Strength and Teacher Quits." Industrial and Labor Relations Review, Vol. 45, No. 1 (October), pp. 31-43.

Roy, Donald. 1952 "Quota Restriction and Goldbricking in a Machine Shop." American Journal of Sociology, Vol. 57 (March), pp. 432-41.

Schacht, John 1985. The Making of Telephone Unionism, 1920-1947. New Brunswick, N.J.: Rutgers University Press.

Shaw, Jason, John Delery, G. Douglas Jenkins, Jr., and Nina Gupta. 1998. "An Organization-Level Analysis of Voluntary and Involuntary Turnover." Academy of Management Journal, Vol. 39, No. 5, pp. 1-15.

Spencer, Daniel G. 1986. "Employee Voice and Employee Retention." Academy of Management Journal, Vol. 29, No. 3, pp. 488-502.

Stone, Katherine V. W. 1996. "Mandatory Arbitration of Individual Employment Rights: The Yellow Dog Contract of the 1990s." Denver University Law Review, Vol. 73, pp. 1017-50.

1999. "Employment Arbitration under the Federal Arbitration Act." Chapter 2 in Adrienne E. Eaton and Jeffrey H. Keefe, eds., Employment Dispute Resolution and Worker Rights in the Changing Workplace. Champaign, Ill.: Industrial Relations Research Association.

Weisman, Carole S., Dorothy L. Gordon, Sandra D. Cassard, Marilyn Bergner, and Rebeca Wong. 1993. "The Effects of Unit Self-Management on Hospital Nurses' Work Process, Work Satisfaction, and Retention." Medical Care, Vol. 31, No. 5, pp. 381-93.

Wilson, Nicholas, and Michael J. Peel. 1991. "The Impact on Absenteeism and Quits of Profit-Sharing and Other Forms of Employee Participation." Industrial and Labor Relations Review, Vol. 44, No. 3 (April), pp. 454-68.

Wyatt Data Services, Cole Surveys. 1991. Restructuring-Cure or Cosmetic Surgery? Results of Corporate Change in the '80s with Rx's for the '90s. Boston: Wyatt. Zack, Arnold M. 1999. "Agreements to Arbitrate and the Waiver of Rights under Employment Law." Chapter 3 in Adrienne E. Eaton and Jeffrey H. Keefe, eds., Employment Dispute Resolution and Worker Rights in the Changing Workplace. Champaign, Ill.: Industrial Relations Research Association. 
Copyright $\odot 2002$ EBSCO Publishing 